\title{
Oral Hygiene Behavior of Croatian Adolescents during Fixed Orthodontic Treatment: A Cross-sectional Study
}

\section{Oralna higijena adolescenata u Hrvatskoj tijekom terapije fiksnim ortodontskim napravama: presječna studija}

Department of Orthodontics, School of Dental Medicine University of Zagreb
Zavod za ortodonciju Stomatološkog fakulteta Sveučilišta u Zagrebu
Received: September 29, 2021 Accepted: November 19, 2021

Address for correspondence Professor Sandra Anić Milošević University of Zagreb, School of Dental Medicine Department of Orthodontics Gundulićeva 5, 10000 Zagreb, Croatia sanic@sfzg.hr

\section{MeSH terms: Home Care Dental} Devices; Adolescent

Author keywords: Adolescence; Oral Hygiene; Fixed Orthodontic Appliances

\section{Introduction}

The attitude towards oral health has been systematically neglected for years and has been based primarily on the removal of the adverse effects on teeth and gingiva that have already occurred. "Despite great efforts put into maintaining oral health, not only in the Republic of Croatia, but the whole world, oral diseases are on the rise" (1). Dental caries is one of the most common diseases among children and adolescents (2). The habit of maintaining oral hygiene is acquired in childhood, where parents play the greatest role by teaching, motivating and getting their children used to maintaining an adequate oral hygiene on daily basis from their earliest age. The transition from early childhood to puberty and adolescence brings along great and important challenges regarding oral health. Even though there is no unique definition of adolescence, it is usually considered to be the period in life which represents the transition from childhood to adulthood, the period between ages 11 and 20. Adolescence is a period of intense physical, psychological and emotional changes, which often results in risk behaviors (e.g. inadequate diet, consumption of alcohol and cigarettes), that
Uvod

Čovjekov odnos prema oralnome zdravlju godinama se sustavno zanemarivao, a temeljio se uglavnom na otklanjanju već nastalih negativnih učinaka na zube i gingivu. „Unatoč velikim naporima uloženima u očuvanje oralnoga zdravlja, ne samo u Republici Hrvatskoj, nego u cijelom svijetu, bolesti usne šuplijine su u porastu." (1), a karijes je jedna od najraširenijih bolesti djece i adolescenata (2). Navika održavanja oralne higijene stječe se u djetinjstvu, u čemu najveću ulogu imaju roditelji koji već u najranijoj dobi moraju učiti, privikavati i motivirati dijete na pravilnu i svakodnevnu oralnu higijenu. Prelazak iz ranoga djetinjstva u pubertet i adolescentno razdoblje donosi sa stajališta oralnoga zdravlja velike i značajne izazove. Iako ne postoje jedinstvene definicije adolescencije, najčešće se smatra da je to razdoblje čovjekova života prelazak iz djetinjstva u svijet odraslih i uglavnom obuhvaća razdoblje između 11. i 20. godine. Adolescencija je razdoblje intenzivnih fizičkih, psiholoških i emocionalnih promjena koje često rezultiraju rizičnim oblicima ponašanja (neadekvatna prehrana, konzumiranje alkohola i cigareta), što znatno utječe na do tada stvorene navike u vezi s oralnim 
might lead to inadequate oral health and hygiene (3). Furthermore, adolescence is a period defined by three types of changes which reflect directly on oral health, i.e.: skeletal development: facial development and teeth positioning, hormonal changes, end of the transition from the primary to permanent dentition (4).

For adolescent patients at the peak of their growth and development, orthodontic treatment is mostly indicated, and irregularities can be successfully corrected by fixed, removable or combined orthodontic appliances. A treatment involving fixed orthodontic appliances promotes the accumulation of food and plaque, and maintaining oral hygiene becomes difficult and demanding. An appliance itself creates plaque retentive sites for dental biofilm, which can lead to enamel demineralization and gingivitis (5).

This research is conducted in order to examine the impact of orthodontic treatment on consumption of certain food and maintenance of oral hygiene. In addition, the aim of this research was to determine which supplemental oral hygiene tools are used among adolescents during orthodontic treatment in the Department of Orthodontics, School of Dental Medicine, University Hospital Centre, Zagreb, Croatia.

\section{Material and methods}

This study was carried out in a form of a survey questionnaire, comprising 23 questions in order to analyze the maintenance of oral hygiene in adolescents. The research questions were divided in several thematic units: Issues related to the impact of orthodontic treatment on food consumption and oral hygiene; Questions that collect information on the manner of implementation and use of supplementary oral hygiene tools; Questions that collect data on demographic and socio-economic characteristics of the respondents.

The $\mathrm{G}^{*}$ Power program (6.7) was used to determine the sample size. For this purpose, $\chi^{2}$ tests (Goodness-of-fit tests) were used, and for noticing an effect of 0.30 (medium effect), with a significance level of 0.05 , strength of 0.8 and two degrees of freedom, the minimum required sample size was 108 subjects.

Our research comprised 170 adolescent patients aged between 11 and 19 (73 males and 97 females), who underwent a treatment with fixed orthodontic appliance at the Department of Orthodontics, School of Dental Medicine, University Hospital Centre, Zagreb, Croatia. Patients data were collected by the investigators M.C.S. i Ž.M. in the period from December 2020 until March 2021. The sample comprised 77 respondents aged between 11 and 13 (45.3\%), 51 respondents aged between 14 and $16(30.0 \%)$ and 42 respondents aged between 17 and 19 (24.7\%). Such representation and distribution of the sample were dictated solely by the current need for dental examinations, i.e. therapies. The treatment (straight-wire technique) consisted of 18-slot metal brackets in the Roth prescription, with 0.010 -inch steel ligatures (Forestadent, Pforzheim, Germany). Since the respondents were mainly minors, informed consents were signed by their parents or guardians who also had an insight into the questionnaire for the entire period until its completion. zdravljem i higijenom (3). Adolescencija je, nadalje, razdoblje obilježeno trima tipovima promjena koje se izravno reflektiraju na oralno zdravlje. To su: skeletni razvoj - razvoj lica i pozicioniranje zuba; hormonalne promjene; završetak prelaska iz mliječne u trajnu denticiju (4).

Kod mladih osoba na vrhuncu rasta i razvoja, odnosno u adolescentnom razdoblju, najčešće se propisuje ortodontska terapija mobilnim, fiksnim ili kombiniranim ortodontskim napravama. Terapija ortodontskim napravama, osobito fiksnima, pogoduje nakupljanju hrane i naslaga na zubima te je održavanje oralne higijene otežano i zahtjevno. Sama naprava stvara retentivna mjesta plaka na kojima nakupljeni biofilm može demineralizirati caklinu i potaknuti gingivitis (5).

Ovo istraživanje provedeno je u namjeri da se dozna u kojoj je mjeri narušena kvaliteta života ispitanika provođenjem ortodontske terapije zbog otežanoga konzumiranja hrane i održavanja oralne higijene te na koje načine i kojim pomagalima i aktivnostima pacijenti (adolescenti) održavaju oralnu higijenu tijekom ortodontske terapije u Zavodu za ortodonciju Kliničkoga bolničkoga centra Zagreb.

\section{Materijal i metode}

Provođenje oralne higijene kod adolescenata analizirano je u istraživanju koje je provedeno u obliku anketnog upitnika od 23 pitanja. U skladu s glavnim ciljem istraživačka pitanja podijeljena su u više tematskih cjelina: pitanja koja se odnose na utjecaj ortodontske terapije na konzumiranje hrane i provođenje oralne higijene; pitanja kojima se prikupljaju informacije o načinu provođenja i upotrebi sredstava za održavanje oralne higijene; pitanja kojima se prikupljaju podatci o demografskim i socioekonomskim karakteristikama ispitanika čiji je cilj omogućiti utvrđivanje eventualnih razlika među pojedinim kategorijama pacijenata kada je riječ o temama obuhvaćenim upitnikom.

U određivanju veličine uzorka korišten je program $\mathrm{G}^{*}$ Power $(6,7)$. Za provođenje $\chi^{2}$ testa (Goodness-of-fit tests) te uočavanje efekta veličine 0,30 (srednji efekt), uz razinu značajnosti od 0,05 i snagu 0,8 te dva stupnja slobode, minimalna potrebna veličina uzorka je 108 ispitanika.

U našem istraživanju sudjelovalo je 170 pacijenata u dobi od 11 do 19 godina (73 ispitanika i 97 ispitanica) koji su bili na terapiji fiksnim metalnim ortodontskim napravama u Klinici za ortodonciju Kliničkoga bolničkoga centra Zagreb. Pacijente su anketirale istraživačice M. C. S. i Ž. M. od prosinca 2020. do ožujka 2021. godine. Sudjelovalo je 77 ispitanika u dobi od 11 do 13 godina (45,3\%), 51 ispitanik u dobi od 14 do 16 godina (30,0\%) te 42 ispitanika u dobi od 17 do 19 godina (24,7 \%). Takva zastupljenost i distribucija uzorka isključivo je bila uvjetovana trenutačnom potrebom za stomatološkim pregledom, odnosno terapijom. U terapiji (tehnika ravnoga luka) korištene su metalne bravice, dimenzije slota 18, preskripcije prema Rothu proizvođača Forestadent te čelične ligature 0,010 " istoga proizvođača. $S$ obzirom na to da su ispitanici uglavnom maloljetni, informirani pristanak potpisali su njihovi roditelji ili skrbnici koji su također imali uvid u anketni upitnik tijekom ispunjavanja. 


\section{Statistical analysis}

The results of the research were processed and analyzed using statistical methods with the software package IBM SPSS, STATISTICS version 23.0 (Osijek, Croatia). To offer the most complete answers to the set hypotheses, the processing of the data collected during research was performed in two stages of statistical procedures. The first stage produced a tabular representation of frequency distribution, whereas the second stage consisted of comparison and determination of statistical significance of differences between categorical variables. Differences in categorical variables were tested by the $\chi 2$-test. The level of statistical significance was set at $\mathrm{P}<$ 0.05 .

The research procedures were carried out following the Decision of the Ethics Committee of the School of Dental Medicine of the University of Zagreb. Research participation was voluntary, whereas the participants were guaranteed anonymity and confidentiality.

\section{Results}

Even though the fixed orthodontic treatment typically requires more effort, attention and additional dental aid during oral hygiene maintenance, the largest number of respondents, i.e. $63.5 \%$, responded that orthodontic appliances did not interfere with their maintenance of oral hygiene, however, $62.4 \%$ of the respondents stated they had issues with the consumption of certain foods (Table 1).

A majority of the respondents, i.e. $55.9 \%$, maintain their oral hygiene twice a day using medium-soft brushes (35\%), (Figure 1).

If the duration of brushing (Figure 2) is taken into consideration, the largest number in all age groups (over $80 \%$ of each group) brush their teeth for over a minute, but there is a significant difference between groups among those who brush their teeth for over a minute (150 respondents), because over $45 \%$ of them represent the youngest population.

\section{Statistička analiza}

Dobiveni rezultati istraživanja obrađeni su i analizirani statističkim metodama u programskom paketu IBM SPSS, STATISTICS verzija 23.0. U svrhu dobivanja što potpunijeg odgovora na postavljene hipoteze, obrada prikupljenih podataka tijekom istraživanja obavljena je u dvije faze statističkih postupaka. U prvoj su tablično prikazane frekvencije distribucije, a u drugoj je uspoređena i određena statistička značajnost razlika kategorijskih varijabli. Razlike kategorijskih varijabli testirane su $\chi 2$-testom. Razina statističke značajnosti postavljena je na $\mathrm{P}<0,05$.

Istraživački postupci provedeni su u skladu s odlukom Etičkoga odbora Stomatološkog fakulteta Sveučilišta u Zagrebu. Sudjelovanje u istraživanju bilo je dobrovoljno, a sudionicima je bila zajamčena anonimnost i povjerljivost podataka.

\section{Rezultati}

Iako terapija fiksnim ortodontskim napravama u pravilu zahtijeva više truda, pažnje i pomoćnih sredstava u održavanju oralne higijene, najveći broj ispitanika, odnosno $63,5 \%$ izjavilo je da im nošenje fiksnih ortodontskih naprava ne otežava oralnu higijenu, ali 62,4\% izjasnilo se da ima problema $s$ konzumiranjem određenih namirnica (tablica 1.).

Najveći broj ispitanika u ovom istraživanju, odnosno $55,9 \%$, higijenu oralne šupljine obavlja dva puta na dan $s$ pomoću srednje tvrde četkice (35\%) (slika 1.).

Ako se promatra trajanje pranja zuba (slika 2.), najveći dio svih dobnih skupina (više od $80 \%$ iz svake skupine) zube pere više od jedne minute, ali od onih koji zube peru više od jedne minute (150 ispitanika) postoji znatna razlika među skupinama jer više od $45 \%$ to čini najmlađa populacija. Od pomoćnih sredstava za održavanje oralne higijene adolescenti, kao što je vidljivo u tablici 2., najčešće se koriste inter-

Table 1 Effect on fixed orthodontic treatment on oral hygiene maintenance and foods consumption

Tablica 1. Utjecaj fiksne ortodontske terapije na održavanje oralne higijene i konzumaciju namirnica

\begin{tabular}{|c|c|c|c|}
\hline & & Frequency $\bullet N$ & Percent $\bullet$ Postotak \\
\hline \multirow{2}{*}{$\begin{array}{l}\text { Was it difficult for you to maintain oral hygiene while in orthodontic } \\
\text { treatment? • Otežava li vam fiksna ortodontska naprava održavanje } \\
\text { oralne higijene? }\end{array}$} & Yes $\bullet \mathrm{Da}$ & 62 & $36.5 \%$ \\
\hline & $\mathrm{No} \cdot \mathrm{Ne}$ & 108 & $63.5 \%$ \\
\hline \multirow{3}{*}{$\begin{array}{l}\text { Was it difficult for you to consume certain foods while in orthodontic } \\
\text { treatment? } \bullet \text { Otežava li vam fiksna ortodontska naprava konzumiranje } \\
\text { odredenih namirnica? }\end{array}$} & Yes $\bullet \mathrm{Da}$ & 106 & $62.4 \%$ \\
\hline & $\mathrm{No} \cdot \mathrm{Ne}$ & 64 & $37.6 \%$ \\
\hline & Total • Ukupno & 170 & $100.0 \%$ \\
\hline
\end{tabular}

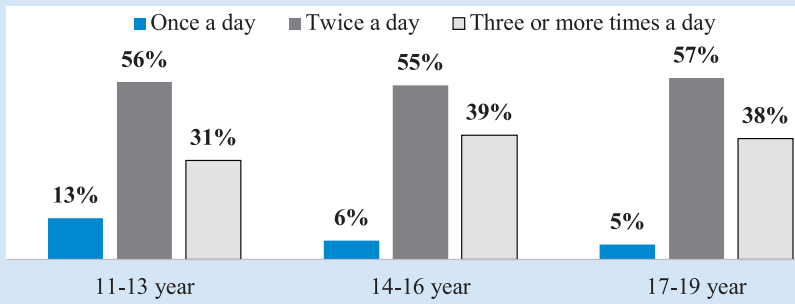

Figure 1 Frequency of brushing in relation to age Slika 1. Učestalost pranja zuba u odnosu prema dobi

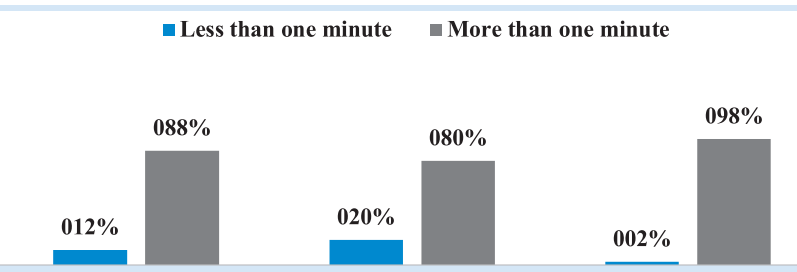

11-13 years 14-16 years 17-19 years

Figure 2 Duration of brushing in relation to age Slika 2. Dužina pranja zuba u odnosu prema dobi 


\begin{tabular}{|c|c|c|}
\hline Interdental toothbrush $\bullet$ Interdentalne četkice & Frequency $\bullet N$ & Percent $\bullet$ Postotak \\
\hline Yes, daily $\bullet \mathrm{Da}$, svakodnevno & 53 & $31.2 \%$ \\
\hline Yes, sometimes $\bullet \mathrm{Da}$, katkad & 70 & $41.2 \%$ \\
\hline $\mathrm{No} \bullet \mathrm{Ne}$ & 47 & $27.6 \%$ \\
\hline Total • Ukupno & 170 & $100.0 \%$ \\
\hline Dental floss $\bullet$ Zubni konac & Frequency $\bullet N$ & Percent $\bullet$ Postotak \\
\hline Yes, daily $\bullet$ Da, svakodnevno & 7 & $4.1 \%$ \\
\hline Yes, sometimes $\bullet \mathrm{Da}$, katkad & 46 & $27.1 \%$ \\
\hline $\mathrm{No} \cdot \mathrm{Ne}$ & 117 & $68.8 \%$ \\
\hline Total • Ukupno & 170 & $100.0 \%$ \\
\hline Mouthwash • Vodica za ispiranje & Frequency $\bullet N$ & Percent $\bullet$ Postotak \\
\hline Yes, daily • Da, svakodnevno & 23 & $13.5 \%$ \\
\hline Yes, sometimes $\bullet \mathrm{Da}$, katkad & 66 & $38.8 \%$ \\
\hline $\mathrm{No} \cdot \mathrm{Ne}$ & 81 & $47.6 \%$ \\
\hline Total $\bullet$ Ukupno & 170 & $100.0 \%$ \\
\hline
\end{tabular}

Table 3 Receiving instructions on oral hygiene maintenance from the orthodontist

Tablica 3. Dobivanje uputa za održavanje oralne higijene od ortodonta

Instructions on oral hygiene maintenance from the orthodontist • Upute za održavanje oralne higijene od ortodonta

Yes, instructions on how to brush your teeth properly •

$\mathrm{Da}$, upute kako pravilno četkati zube

Yes, instructions on using an interdental brush, dental floss or mouthwash •

$\mathrm{Da}$, upute kako upotrebljavati interdentalnu četkicu, konac i vodicu za ispiranje

Yes, instructions on proper nutrition $\bullet \mathrm{Da}$, upute o pravilnoj prehrani

$\mathrm{No} \cdot \mathrm{Ne}$

Total $\bullet$ Ukupno

\begin{tabular}{|c|c|c|}
\hline Frequency $\bullet \mathbf{N}$ & Percent $\bullet$ Postotak & $\begin{array}{c}\text { Percent of cases } \\
\text { Postotak slučajeva }\end{array}$ \\
\hline $\mathbf{1 3 6}$ & $48.7 \%$ & $80.0 \%$ \\
\hline 72 & $25.8 \%$ & $42.4 \%$ \\
\hline 63 & $22.6 \%$ & $37.0 \%$ \\
\hline 8 & $2.9 \%$ & $4.7 \%$ \\
\hline 279 & $100.0 \%$ & $164.1 \%$ \\
\hline
\end{tabular}

Regarding additional dental aids for oral hygiene maintenance, adolescents mostly use interdental brushes (see $\mathrm{Ta}$ ble 2), which are used daily, or sometimes, they are used by $72.4 \%$ of adolescent respondents in treatments with fixed orthodontic appliances. The relationship with chosen orthodontist, where trust and effective communication may lead to the prevention of oral diseases and enhancement of oral health, plays an important role in development of hygiene habits and oral health maintenance while in treatment with fixed appliances.

When asked: "Have you received instructions regarding hygiene maintenance during orthodontic treatment from your orthodontist?" the respondents could choose among multiple answers, the total number of which is given in Table 3. In the research, $41.8 \%$ of the respondents stated that they had been warned about unsatisfactory oral hygiene, which suggests that a large number of adolescents do not maintain adequate oral hygiene, even though $91.2 \%$ of them stated they brushed their teeth two or more times a day.

\section{Discussion}

Orthodontic elements such as brackets, bands and wires make daily hygiene more difficult because they create plaque retentive areas which are hard to clean with regular brushes (8) and it is mandatory for the patient to establish a satisfactory oral hygiene before any orthodontic treatment (9). dentalnom četkicom koju svaki dan ili katkad upotrebljava $72,4 \%$ ispitanika adolescenata u terapiji fiksnim ortodontskim napravama. Posebno značenje na putu usvajanja te razvijanja higijenskih navika i održavanju oralnoga zdravlja tijekom terapije fiksnim ortodontskim napravama, ima odnos s odabranim ortodontom koji, na temelju povjerenja i kvalitetne komunikacije, može znatno prevenirati oralne bolesti i poboljšati oralno zdravlje.

Na pitanje: ,Jeste li od ortodonta dobili upute za održavanje higijene tijekom ortodontske terapije" ispitanici su odabirali više ponuđenih odgovora čiji je ukupan broj naznačen u tablici 3. U provedenom istraživanju $41,8 \%$ ispitanika navelo je da su upozoreni na nezadovoljavajuću oralnu higijenu, što upućuje da velik broj adolescenata ne održava pravilno oralnu higijenu, iako ih je 91,2 \% izjavilo da peru zube dva ili više puta na dan.

\section{Rasprava}

Ortodontski elementi, kao što su bravice, tube i žice otežavaju svakodnevnu higijenu jer stvaraju retentivna mjesta plaka koja se teško čiste običnim četkicama (8) pa je zbog toga nužno da pacijenti prije početka ortodontske terapije usvoje pravilne higijenske navike (9). Ispitanici iz ove studi- 
The study subjects stated that the appliance itself did not interfere with their oral hygiene maintenance which they carried out two times a day. A study carried out at the Faculty of Dental Medicine in Thailand, in which subjects were aged between 13 and 41 (mean age: 20 years) shows slightly more optimistic results because over $50 \%$ of the respondents brush their teeth after each meal (10). Unfortunately, the researchers did not make a distinction within the group, which could answer the question of whether the awareness of oral hygiene was growing with years during the orthodontic treatment. The authors of a study carried out in Lithuania on a sample of patients similar to ours showed that older adolescents (aged 16 to 18) paid more attention to oral hygiene maintenance than the younger ones (aged 12 to 15) (8). The results of their study are supported by this research as well since only two respondents in the oldest group (4.8\%) stated that they brushed their teeth only once a day.

Even though some studies suggest that there is a difference in the frequency of brushing between the genders to the advantage of the females (8), a statistically significant difference between the genders was not found in this study.

The patients included in this study stated that an orthodontic appliance did not interfere with their maintenance of oral hygiene, however over $60 \%$ of the respondents pointed out that this treatment made the consumption of certain foods more difficult. Some studies suggest that before orthodontic treatment, patients are not worried about diet limitations, but rather focus on the esthetics and treatment outcomes instead. However, while in the treatment, the main complaints are directed to the difficulties of the solid foods intake, as well as the pain in the first stages of the leveling phase as well as periods following orthodontic follow-up examinations (11). The reasons for the food intake difficulties are surely caused by the pain in the first days after the appliance was bonded as well because chewing food is painful and many patients avoid solid foods. Moreover, doctors provide instructions for patients regarding proper diet during the bonding of an orthodontic appliance to prevent any damages to the appliance itself. It has been recorded that patients mostly avoid consuming apples, carrots, chips, nuts, chewing gums, crackers and popcorn and that they believe they have improved their dietary habits during the orthodontic treatment, either by changing meal preparation methods, reducing the intake of "unhealthy food", or reducing the number of snacks between the meals (12). A study that analyzed the patients' diet three days before and three days after starting orthodontic treatment or after follow-up examinations, showed that due to the painful sensations, the patients consumed softer foods. Consequently, this led to decreased levels of copper, magnesium and fiber in their diets and increased the intake of fat. The authors, therefore, recommend nutritional counselling for all the patients who consume soft, liquid foods (13). The studies that have compared diets of adolescents in the orthodontic treatment with fixed orthodontic appliances and control groups of adolescents (without orthodontic appliances) have shown that the former group consumed more total fats, saturated fats, monounsaturated fats, polyunsaturated fats, linolenic fat, linoleic fat and cholester- je izjasnili su se da ih sama naprava ne ometa u održavanju oralne higijene koju, najčešće, obavljaju dva puta na dan. Studija provedena na Fakultetu dentalne medicine u Tajlandu u kojoj su ispitanici bili u dobnoj skupini od 13 do 41 godine, (srednja dob 20 godina) pokazuje ipak malo optimističnije rezultate jer više od $50 \%$ ispitanika zube pere nakon svakog obroka (10). Nažalost istraživači nisu napravili distinkciju unutar skupine koja bi možda dala odgovor raste li s godinama svijest o oralnoj higijeni tijekom ortodontske terapije. Autori studije provedene u Litvi na sličnom su uzorku pacijenata kao u ovom istraživanju pokazali da stariji adolescenti (16 do 18 godina) posvećuju više pozornosti održavanju oralne higijene od onih mlađih (12 do 15 godina) (8). Takve rezultate podupire i ovo istraživanje, pa su tako u najstarijoj skupini samo dva ispitanika $(4,8 \%)$ navela da zube peru samo jedanput na dan.

Iako se u studijama ističe da postoji razlika u frekvenciji pranja zuba između spolova, u korist žena (8), u ovom istraživanju nismo pronašli statistički značajnu razliku među spolovima.

Pacijenti uključeni u studiju naveli su da ih ortodontska naprava ne ometa u održavanju oralne higijene, ali njih više od $60 \%$ istaknulo je kako im ova terapija smeta pri konzumaciji određenih namirnica. U nekim istraživanjima autori ističu da pacijente prije početka ortodontske terapije ne zabrinjava podatak o limitima u prehrani tijekom terapije, nego su fokusirani na estetski dojam i ishod. Ipak, za trajanja terapije glavne pritužbe usmjerene su na otežan unos krutih namirnica te na bolove koji su pojavljuju u početnim fazama nivelacije i nakon ortodontskih kontrola (11). Razlozi za otežani unos hrane sigurno su i bolovi u prvim danima poslije postavljanja naprave kad je žvakanje bolno i mnogi pacijenti izbjegavaju krutu hranu. Uz to, doktori poslije postavljanja ortodontske naprave pacijentima daju upute o pravilnom načinu prehrane kako ne bi oštetili samu napravu. Zabilježeno je da pacijenti najčešće izbjegavaju jabuke, mrkvu, čips, orašaste plodove, žvakaće gume, krekere i kokice te kako smatraju da su tijekom ortodonstke terapije poboljšali svoje prehrambene navike, bilo promjenom načina pripreme obroka, bilo smanjenim unosom „nezdrave hrane ili redukcijom međuobroka (12).

Studija u kojoj je analizirana prehrana pacijenata tri dana prije početka ortodontske terapije i tri dana poslije njezina početka, ili nakon ortodontske kontrole pokazala je da su pacijenti nakon bolne senzacije jeli mekšu hranu te je taj način prehrane rezultirao padom razine bakra i magnezija u prehrani i manjim unosom vlakana, a povećanim unosom masnoća. Zato autori preporučuju dijetetsko savjetovanje pacijentima koji jedu mekanu, tekuću hranu (13). Istraživanja u kojima je uspoređivana prehrana adolescenata tijekom ortodontske terapije fiksnim ortodontskim napravama s kontrolnom skupinom adolescenata (bez ortodontske naprave) pokazala su da prva skupina unosi više ukupnih masnoća, zasićenih masti, jednostruko zasićenih masti, polizasićenih masti, linolenske masti, linolne masti i kolesterola, a znatno manje vlakana, kroma i betakarotena, iako je ukupan kalorijski unos u objema skupinama podjednak (14). 
ol, but showed significantly lower intakes of fiber, chromium and beta-carotene, even though the total caloric intake was about the same in both groups (14).

The oral hygiene maintenance tools market offers a wide range of options available for buyers to choose from. As this study has shown, most respondents use regular (manual) brushes for oral hygiene maintenance which they usually change every two to three months. The largest numbers of respondents, (72.4\%), have stated that, besides regular or electric brushes, they used interdental brushes, whereas $68.8 \%$ of the surveyed population did not use dental floss. "The choice of an interdental oral hygiene maintenance device should primarily be defined by the size and shape of the interdental space, teeth position and location as well as the patient's capabilities and motivation. Interdental spaces are the starting point for the development of periodontal diseases, including dental caries, which increases the importance of everyday use of interdental devices for oral hygiene maintenance" (15). Mouthwashes were, according to the data of this study, used by over $50 \%$ of the surveyed population.

In the final part of the questionnaire, the respondents were asked whether they had received instructions from their orthodontists on proper brushing, use of additional dental aids for oral hygiene and proper diet. They could circle multiple answers. Most respondents, $(80 \%)$, stated that they had been given instructions on proper brushing, $43.5 \%$ of them answered that they had been given instructions on the use of the interdental brush, dental floss or mouthwash, whereas $36.5 \%$ of the respondents received instructions on proper diet. Slightly less than $5 \%$ of the respondents stated they had not received any instructions from their orthodontists (Table 3). The results regarding instructions on oral hygiene are in accordance with the results of other studies, which suggests that patients received instructions in $82.9 \%$ of cases. Instructions on adequate diet were given to $43.8 \%$ of patients, and it is apparent that patients are less informed in this study on the importance of an adequate diet (16). A study carried out in Great Britain on a large number of orthodontists showed that all orthodontists provide information to their patients on proper brushing, whereas $84 \%$ of them provide information on proper diet during the orthodontic treatment (17). They stated that they have started using mobile applications only recently to improve patients' motivation for brushing (18). These data differ significantly from the data in our study, thus suggesting that Croatian orthodontists should become more involved. Considering adolescence as a very sensitive period, in which diet plays an important role and is required for proper growth and development of young persons, the results of this study have shown that more time needs to be dedicated to the education of patients on proper diet during the orthodontic treatment. Azaripour et al. suggest that during each follow-up examination patients need to be warned of regular and adequate oral hygiene maintenance because, even though they receive instructions at the beginning of the treatment, they do not implement them in their daily routines. Unlike the control group, the respondents who had undergone the fixed orthodontic appliances treatment suffered from gingivitis caused by plaque accumulation on teeth (19). Besides in-
Tržište pribora za održavanje oralne higijene nudi niz mogućnosti koje kupci mogu iskušati. Ovo istraživanje pokazalo je da se većina ispitanika koristi običnom (manualnom) četkicom za održavanje oralne higijene koju najčešće mijenjaju svaka dva do tri mjeseca. Ovo istraživanje također je pokazalo da najveći broj ispitanika $(72,4 \%)$ upotrebljava, osim običnih ili električnih četkica, i interdentalne četkice za zube, a zubnim koncem ne koristi se $68,8 \%$ ispitane populacije. „Odabir interdentalnoga sredstva za održavanje oralne higijene trebao bi primarno biti definiran veličinom i oblikom interdentalnoga prostora, pozicijom i smještajem zuba te sposobnošću i motivacijom pacijenta. Interdentalni prostori početna su točka za nastanak parodontne bolesti, ali i karijesa, što povećava značenje svakodnevne upotrebe interdentalnih sredstava za održavanje oralne higijene"(15). Vodicu za ispiranje zuba, prema podatcima iz ovog istraživanja, upotrebljava više od $50 \%$ ispitane populacije.

U posljednjem dijelu upitnika ispitanici su odgovarali na pitanja jesu li od ortodonta dobili upute o pravilnom četkanju zuba, upute o korišstenju pomoćnih sredstava u oralnoj higijeni te upute o pravilnoj prehrani. Imali su mogućnost zaokružiti nekoliko odgovora. Najviše ispitanika, njih čak $80 \%$, odgovorilo je da su dobili upute o pravilnom četkanju zuba, 43,5 \% zaokružilo je da su dobili upute o korištenju interdentalne četkice, zubnog konca ili vodice za ispiranje zuba, a upute o pravilnoj prehrani dobilo je 36,5\% ispitanika. Nešto manje od $5 \%$ ispitanika istaknulo je da nisu dobili nikakve upute od svojega ortodonta (tablica 3.). Dobiveni rezultati, kad je riječ o uputama o oralnoj higijeni, u skladu su s rezultatima drugih studija u kojima se navodi da su upute o oralnoj higijeni pacijenti dobili u 82,9\% slučajeva. Upute o pravilnoj prehrani dobilo je 43,8 \% pacijenata te je jasno da su pacijenti u ovom istraživanju slabije informirani o važnosti pravilne prehrane (16). Istraživanje provedeno u Velikoj Britaniji na velikom broju ortodonata pokazuje da svi svojim pacijentima daju upute o pravilnom četkanju zuba, a $84 \%$ daje i podatke o pravilnoj prehrani tijekom ortodontske terapije (17). Nedavno su počeli upotrebljavati i mobilne aplikacije kako bi motivirali pacijente na održavanje higijene (18). Ti podatci bitno se razlikuju od podataka u ovom istraživanju i upozoravaju na prostor u kojemu se ortodonti trebaju više aktivirati. S obzirom na to da je adolescencija vrlo osjetljivo razdoblje u kojemu je prehrana veoma važna jer je nužna za pravilan rast i razvoj mladih osoba, rezultati ove studije upućuju na to da treba više vremena posvetiti edukaciji pacijenata o pravilnoj prehrani tijekom ortodontske terapije. Azaripour i suradnici navode da se pacijenti tijekom svake ortodontske kontrole moraju upozoravati na redovitu i adekvatnu oralnu higijenu jer, iako su na početku terapije dobili upute, nisu ih implementirali u svakodnevnu rutinu. Za razliku od kontrolne skupine, skupina ispitanika koja je bila na terapiji fiksnim ortodontskim napravama patila je od gingivitisa prouzročenoga akumulacijom plaka na zubima (19). Uz upute ortodonti bi pacijentima trebali davati i određena upozorenja. U provedenom istraživanju 71 ispitanik $(41,8 \%)$ naveo je da je upozoren na nezadovoljavajuću oralnu higijenu, što pokazuje da velik broj adolescenata, iako je najveći broj njih dobio upute, ne 
structions, orthodontists should provide specific warnings to their patients as well. In our research, 71 respondents (41.8\%) stated that they had been warned about unsatisfactory oral hygiene, which suggests that a large number of adolescents do not maintain adequate oral hygiene, even though a majority of them have been given instructions. By crossing brushing frequency variables with the variable of warning of the inadequacy of their oral hygiene, a statistically significant difference between the present variables has been noticed ( $(\mathrm{DF}=2$, $\mathrm{P}=<0.05)$. We may, therefore, conclude that the warning about inadequate oral hygiene was given mostly to those who brushed their teeth once a day (73.7\%), (Table 4). održava pravilno oralnu higijenu. Križanjem varijabli učestalosti pranja zuba s varijablom upozorenja da nijhova oralna higijena nije zadovoljavajuća, uočena je statistički značajna razlika između navedenih varijabli $(\mathrm{DF}=2, \mathrm{P}=<0,05)$. Tako se može zaključiti kako je upozorenje da im je higijena nezadovoljavajuća dobilo najviše onih koji peru zube jedanput na dan (73,3\%) (tablica 4.).

Nadalje, ovo istraživanje pokazalo je da je uloga ortodonta i njegovo aktivno djelovanje u edukaciji i kontroli usvajanja navika oralne higijene sigurno značajna i adolescentima pruža veliku, ako ne i najveću motivaciju za pravilno održavanje oralne higijene, jer njih 96,5\% smatra da ih je ortodont

Table 4 Orthodontists' warnings of oral hygiene and brushing frequency

Tablica 4. Upozorenja ortodonta o oralnoj higijeni i frekvenciji četkanja zuba

\begin{tabular}{|c|c|c|c|}
\hline \multirow{2}{*}{$\begin{array}{l}\text { How many times a day do you brush your } \\
\text { teeth? } \bullet \text { Koliko puta dnevno četkate zube? }\end{array}$} & \multicolumn{3}{|c|}{$\begin{array}{l}\text { During your appointment with the orthodontist, are you warned that your oral hygiene is not } \\
\text { satisfactory? } \bullet \text { Prilikom posjeta ortodontu jeste li upozoreni da vaša higijena nije zadovoljavajuća? }\end{array}$} \\
\hline & Yes $\bullet \mathrm{Da}$ & $\mathrm{No} \cdot \mathrm{Ne}$ & Total • Ukupno \\
\hline Once a day $\bullet$ Jedanput na dan & $73.3 \%$ & $26.7 \%$ & $100.0 \%$ \\
\hline Twice a day $\bullet$ Dva puta na dan & $41.9 \%$ & $58.1 \%$ & $100.0 \%$ \\
\hline $\begin{array}{l}\text { Three or more times a day } \bullet \text { Tri ili više puta } \\
\text { na dan }\end{array}$ & $35.0 \%$ & $65.0 \%$ & $100.0 \%$ \\
\hline
\end{tabular}

Furthermore, this study pointed to the significant role of the orthodontist and his/her active involvement in the education, control and adoption of oral hygiene habits. It provides to adolescents great, if not the biggest, motivation for adequate oral hygiene maintenance since $96.5 \%$ of respondents reported that their orthodontist motivated them sufficiently regarding proper hygiene maintenance, whereas only $3.5 \%$ of them stated otherwise, i.e. that they had not been sufficiently motivated by their orthodontists.

Due to sample-related limitations (the majority of parents had the same level of education), it was not possible to examine the impact of parents' level of education on maintaining children's oral hygiene. Additional research is needed to examine the factors that influence the selection of supplementary oral hygiene tools, such as the parents' level of education, the financial situation, the number of household members etc.

\section{Conclusions}

The results of this study showed that during the treatment with fixed orthodontic appliances, patients need to change their dietary habits since the appliance interferes with consumption of certain foods. More than half of the respondents stated that the orthodontic appliance did not interfere with their oral hygiene maintenance. This study showed that the majority of the respondents (72.4\%) used interdental brushes, more than $50 \%$ of the respondents used antiseptic mouthwashes for mouth rinsing, whereas only $31.2 \%$ of the tested population used dental floss (4.1\% of which daily). Orthodontists provide their patients with detailed information on oral hygiene maintenance, but they do not provide sufficient information on adequate diet during the fixed orthodontic treatment. dovoljno motivirao na pravilno održavanje higijene, a samo je 3,5\% izjavilo da ih ortodont nije motivirao.

Ograničenje ove studije jest to što zbog ovakvog uzorka (velika većina roditelja imala je jednak stupanj obrazovanja) nije bilo moguće ispitati utjecaj stupnja obrazovanja roditelja na održavanje oralne higijene djece. Potrebna su dodatna istraživanja da bi se ispitali čimbenici koji utječu na odabir dodatnih sredstava za održavanje oralne higijene, kao što su stupanj obrazovanja roditelja, financijsko stanje, broj članova kućanstva i slično.

\section{Zaključak}

Rezultati ove studije pokazali su da pacijenti tijekom terapije fiksnim ortodontskim napravama moraju mijenjati svoje prehrambene navike jer ih ortodontska naprava ometa u konzumiranju određenih namirnica. Više od polovine ispitanika istaknulo je pak da ih naprava ne ometa u održavanju oralne higijene. Ovo istraživanje pokazalo je da se najveći broj ispitanika $(72,4 \%)$ koristi, osim običnim ili električnim četkicama za zube, i interdentalnima. Više od $50 \%$ ispitanika antiseptičkom vodicom ispire usnu šupljinu, a zubnim koncem koristi se tek $31,2 \%$ ispitane adolescentske populacije (od kojih samo 4,1 \% svaki dan). Ortodonti svoje pacijente podrobno informiraju o održavanju oralne higijene, ali nedovoljno ih obavještavaju o pravilnoj prehrani tijekom terapije fiksnim ortodontskim napravama. 


\section{Conflict of interest}

None declared.

Author's contribution: M.Č.Š., M.L.V. conceptualized and wrote the study; S.A.M. participated in acquision and interpretation of data and review of the first draft; Ž.M. participated in acquision of data.

\section{Sukob interesa}

Autori nisu bili u sukobu interesa.

Doprinos autora: M. Č. Š., M. L. V. - koncipirali i napisali studiju; S. A. M. - sudjelovala u prikupljanju i interpretaciji podataka te u pregledu prvog nacrta; Ž. M. - sudjelovao u prikupljanju podataka.
Sažetak

Svrha rada: Željelo se ispitati kakav je utjecaj fiksne ortodontske terapije na konzumaciju hrane i održavanje oralne higijene kod adolescenata te njihova motiviranost za njezino održavanje. Materijal i metode: $\mathrm{U}$ tu je svrhu provedeno istraživanje u obliku anketnog upitnika od 23 pitanja, a sudjelovalo je 170 pacijenata adolescentne dobi od 11 do 19 godina koji su bili na terapiji fiksnim metalnim ortodontskim napravama u Klinici za ortodonciju Kliničkoga bolničkoga centra Zagreb. Rezultati: Istraživanje je pokazalo da ortodontska naprava ne smeta pacijentima u održavanju oralne higijene, ali im otežava konzumaciju određenih namirnica. Najveći broj adolescenata zube pere dva puta na dan i koristi se srednje mekanom četkicom (35\%). Od pomoćnih sredstava $72,4 \%$ ispitanika upotrebljava interdentalne četkice za zube, više od $50 \%$ koristi se antiseptičkom vodicom za ispiranje usne šupljine. Zubnim koncem koristi se tek $31,2 \%$ ispitane populacije (od kojih samo 4,1 \% svakodnevno). Ispitanike su uglavnom na održavanje oralne higijene motivirali njihovi ortodonti (96,5\%), ali samo mali dio ispitanika upućen je u važnost pravilne prehrane tijekom fiksne ortodontske terapije. Zaključak: Ortodonti svojim pacijentima trebaju davati detaljne upute o održavanju higijene te o pravilnoj prehrani za trajanja ortodontske terapije kako bi se minimalizirale negativne nuspojave fiksne ortodontske terapije. Pacijenti se trebaju motivirati tijekom svakoga kontrolnog pregleda te poticati da se u svakodnevnoj rutini koriste sa što više pomoćnih sredstava.
Zaprimljen: 29. rujna 2021.

Prihvaćen: 19. studenoga 2021.

Adresa za dopisivanje

prof. dr. sc. Sandra Anić Milošević

Sveučilište u Zagrebu

Stomatološki fakultet - Zavod za

ortodonciju

Gundulićeva 5

10000 Zagreb, Hrvatska

sanic@sfzg.hr

MeSH terms: uređaji za kućnu njegu zubi; adolescenti

Ključne riječi: adolescencija, oralna higijena, fiksne ortodontske naprave

\section{References}

1. Ministarstvo zdravlja Republike Hrvatske. Povjerenstvo za promicanje i zaštitu oralnog zdravlja. Strateški plan promicanja i zaštite oralnog zdravlja 2015-2017. Zagreb. 2015; 2:4:8-14.

2. Giugliano D, d'Apuzzo F, Majorana A, Campus G, Nucci F, FloresMir C, Perillo L. Influence of occlusal characteristics, food intake and oral hygiene habits on dental caries in adolescents: a crosssectional study. Eur J Paediatr Dent. 2018 Jun; 19(2):95-100.

3. Smith GL, McGuinness TM. Adolescent Psychosocial Assessment: The HEEADSSS. J Psychosoc Nurs Ment Health Serv. 2017 May 1; 55(5):24-27.

4. Sawyer SM, Azzopardi PS, Wickremarathne D, Patton GC. The age of adolescence. Lancet Child Adolesc Health. 2018 Mar; 2(3):223 228.

5. Zibar Belašić T, Žigante M, Perković V, Uhač M, Stjepan Š. Comparison of dental and periodontal condition of patients unexposed and exposed to metal orthodontic appliance. 7th International Congress of the School of Dental Medicine University of Zagreb. Acta stomatol Croat. 2021; 55(2):213-236.

6. Faul F, Erdfelder E, Buchner A, Lang, A. Statistical power analyses using $G *$ Power 3.1: Tests for correlation and regression analyses. Behav Res Methods. 2009 Nov;41(4):1149-60. doi: 10.3758/ BRM.41.4.1149.

7. Faul F, Erdfelder E, Buchner A, Lang, A. G*Power 3: A flexible statistical power analysis program for the social, behavioral, and biomedical sciences. Behav Res Methods. 2007 May;39(2):17591.

8. Jurela A, Sudarević K, Budimir A, Brailo V, Lončar Brzak B, Janković, B. Clinical and Salivary Findings in Patients with Different Types of Orthodontic Brackets. Acta Stomatol Croat. 2019 Sep;53(3):224-230.
9. Tadić K, Katić $\bigvee$, Špalj S. Varies Experience in Patients Referred for an Orthodontic Consultation. Acta Stomatol Croat. 2018; 52(2), 123-131.

10. Anuwongnukroh N, Dechkunakorn S and Kanpiputana R. Oral Hygiene Behavior during Fixed Orthodontic Treatment. Dentistry 2017;7:10.

11. Bradley E, Shelton A, Hodge T, Morris D, Bekker H, Fletcher S, Barber S. Patient-reported experience and outcomes from orthodontic treatment. J Orthod. 2020 Jun;47(2):107-115.

12. Al Jawad FA, Cunningham SJ, Croft N, Johal A. A qualitative study of the early effects of fixed orthodontic treatment on dietary intake and behaviour in adolescent patients, European Journal of Orthodontics. 2012 Aug;34;(4):432-6

13. Riordan DJ. Effects of orthodontic treatment on nutrient intake. Am J Orthod Dentofacial Orthop. 1997 May;111(5):554-61

14. Shirazi AS, Mobarhan MG, Nik E, Kerayechian N, Ferns GA. Comparison of dietary intake between fixed orthodontic patients and control subjects. Aust Orthod J. 2011 May;27(1):17-22.

15. Glažar I, Bakarčić D, Ivančić Jokić N, Katić V, Kovačević Pavičić D, Kuiš D, Prpić J, Simonić-Kocijan S. Priručnik oralne higijene. Rijeka: Medicinski fakultet Sveučilišta u Rijeci; 2017; 21-38.

16. Bhardwaj KV, Sharma RK, Luthra RP, Jhingta P, Sharma D, Justa A. J Educ Health Promot. 2013 Jul 31;2:33.

17. Hobson RS, Clark JD. How UK orthodontists advise patients on oral hygiene., British Br J Orthod. 1998 Feb;25(1):64-6.

18. Patil S, Hedad IA, Jafer AA, Abutaleb GK, Arishi TM, Arishi SA, et al. Effectiveness of mobile phone applications in improving oral hygiene care and outcomes in orthodontic patients. J Oral Biol Craniofac Res. 2021 Jan-Mar;11(1):26-32.

19. Azaripour A, Willershausen I, Hassan M, Ebenezer S, Willershausen B. Oral hygiene and dietary habits in adolescents with fixed orthodontic appliances: A crosssectional Study. J Contemp Dent Pract. 2016 Mar 1;17(3):179-83. 